\title{
In Vitro $\alpha$-Glucosidase Inhibition and Antioxidant Activity of Mulberry (Morus Alba L.) Leaf Ethanolic Extract
}

\author{
Hasim $^{1 *}$, Widia Ayu Lestari' ${ }^{1}$, Uci Sugiman ${ }^{1}$, Didah Nur Faridah ${ }^{2,3}$ \\ ${ }^{1}$ Department of Biochemistry, Faculty of Mathematics and Natural Sciences, \\ IPB University, Bogor 16680, Indonesia \\ ${ }^{2}$ Department of Food Science and Technology, Faculty of Agricultural Engineering and Technology, \\ IPB University, Bogor 16680, Indonesia \\ ${ }^{3}$ Southeast Asian Food \& Agriculture Science \& Technology (SEAFAST) Center, \\ IPB University, Bogor 16680, Indonesia
}

\begin{abstract}
This present work aimed to investigate the in vitro antioxidant activity and $\alpha$-glucosidase inhibitory effect of mulberry leaf ethanolic extract. Antioxidant analysis was performed using Thiobarbituric Acid (TBA) assay at concentrations of $125,200,500$, and $1,000 \mathrm{ppm}$. The results showed that the optimum incubation time was four days and the extracts could reduce the formation of MDA, i.e. $41.21 \%, 45.33 \%$, $44.19 \%$, and $36.00 \%$, respectively. This suggests that concentration of $200 \mathrm{ppm}$ was found as the best treatment. In addition, the result showed that ethanolic extract of mulberry leaf also showed inhibition against $\alpha$-glucosidase with the $\mathrm{IC}_{50}$ of $309.82 \mu \mathrm{g} / \mathrm{mL}$.
\end{abstract}

Keywords: $\alpha$-glucosidase, antioxidant, mulberry, thiobarbituric acid

\section{INTRODUCTION}

Free radical is an atom or group of atoms that possess one or more unpaired electrons, which make it highly chemically reactive towards electrons in other molecules of human cells (Amrun et al. 2007). It causes disruption of important macromolecules such as protein, lipid, carbohydrate, and DNA, which in turn causing physiological disorders such as diabetes mellitus (DM). Nowadays, the prevalence of DM has been growing around the globe, especially type 2 diabetes mellitus (T2DM). Factors contributing to the disease are aging, social-economic problems, lifestyle, lack of physical activities, and obesity (WHO 2015). In addition, glycemia was proposed as another contributor to T2DM (Barclay et al. 2008).

A noticeable increase in glucose level after carbohydrate loading (postprandial glycemia) that exceeds the normal level (hyperclycemia postprandial) is deemed as one of the significant factors causing T2DM (Barclay et al. 2008). One way to control postprandial glycemia is via inhibition of glucose absorption in the intestine. In this case, inhibiting the action of intestinal enzymes, such as $\alpha$-glucosidase, that converts carbohydrate into glucose can be a promising attempt (Castellano et al. 2013). This inhibitory action against $\alpha$-glucosidase is meaningful in management of DM.

Mulberry (Morus alba L.) has been reported as a source of glucose inhibitors (Efendi et al. 2010) and widely used for various diseases such as diabetes, hyper cholesterolemia, and kidney diseases (Huang et al. 2013). The beneficial properties of the plant are attributed to its active compounds such as alkaloid, flavonoid, polyphenol, Calcium, Phosphor, Iron, Manganese, vitamins (A, B, C). Numerous reports have been published regarding the physiological effects of mulberry leaf extracts in controlling glucose level after carbohydrate consumption (Chung et al. 2013; Jeszka-Skowron et al. 2014), while the extract was known as capable of alleviating the absorption of sucrose and maltose in intestine. Intake of mulberry leaf ethanolic and asetone extracts in streptozotocin (STZ)-induced diabetic rats remarkably reduced glucose level, while also increased insulin concentration and antioxidant activity (Jezka-Skowron et al. 2014).

A study on antioxidant activity of mulberry twig and root bark extract estimated using DPPH assay showed protective activities on phospho-

"Corresponding Author: tel: +681319209692, email: hasimdea@yahoo.com 
lipids against free radical attacks; the extract was also effective in avoiding biomolecules from oxidative disruption (Chang et al. 2011). The anti oxidant activity of mulberry leaves extracted using different solvents (acetone, methanol, aqueous) were also investigated. The research found that the methanol extract exhibited the highest content of phenolic and antioxidant activity (ArabshahiDelouee \& Urooj 2007).

Further, Jeszka-Skowron et al. (2014) demonstrated that mulberry leaf extract isolated with ethanol $65 \%$ showed the strongest action on alleviating glucose level of experimental animals. In addition, the experiment showed that such glucose level-lowering effect contributed to increace secretion of insulin and antioxidant activity. However, there is no any scientific report on in vitro experiment uncovering the effects of mulberry leaf ethanolic extract on inhibition of $\alpha$-glucosidase. This present work aimed to investigate the antioxidant activity using TBA (Thiobarbituric Acid) assay, and evaluate the inhibitory properties of mulberry leaf ethanolic extract against $\alpha$-glucosidase.

\section{METHODS}

\section{Design, location, and time}

Antioxidant activity was evaluated according to Completely Randomized Design (CRD) consisting of three groups: negative control (distilled water), positive control ( $\alpha$-tocopherol) at concentration of $200 \mathrm{ppm}$, and mulberry leaf ethanolic extract at various levels $(125,200,500$ and $1,000 \mathrm{ppm}$ ). Each experimental unit was carried out at triplicates.

\section{Materials and tools}

Mulberry leaves were collected from UKBB, Indonesia. Chemicals used were ethanol $65 \%$. Ethanol 30\%, chloroform, ammonia, $\mathrm{H} 2 \mathrm{SO} 4$, Dragendorf reagent, Meyer reagent, Wagner reagent, $\mathrm{FeCl} 3$, ether, $\mathrm{NaOH} 10 \%$ were used for phytochemical analysis. In terms of MDA analysis and incubation time determination, some chemicals were used, including ethanol 70\%, absolute ethanol, linoleic acid $50 \mathrm{mM}$, buffer phosphate $0.1 \mathrm{M} \mathrm{(pH} \mathrm{7),} \alpha$-tocopherol (vitamin E), TMP (1,1,3,3-tetramethoxypropane) 6 M, TCA (trichloroacetic acid), TBA (thiobarbituric acid), and glacial acetic acid. Chemicals used for $\alpha$-glucosidase inhibition analysis included
DMSO (Dimethyl Sulfoxide), $\alpha$-glucosidase, p-nitrophenyl- $\alpha$-D glucopyranoside (p-NPG), natrium bicarbonate $\left(\mathrm{Na}_{2} \mathrm{CO}_{3}\right)$, buffer phosphate, bovine serum albumin (BSA), starch, alloxan, and acarbose (Glucobay). All chemicals used are analytical grade.

Experimental instruments for antoxidant activity analysis were oven, electrical blender, shaker, filter paper, spectrophotometer, centrifuge. While, the instruments used for sample preparation and inhibition analyss were oven, rotary evaporator, microplate, microplate reader Bio Rad, digital balance, vortex.

\section{Procedure}

Preparation of mulberry leaf powder (Jeszka-Skowron et al. 2009). Mulberry leaves were sorted (young leaf, bright green-dark green in color, no blackspots). The sorted leaves were washed, shredded, and sun-dried for 1 hour. Next, the leaves were re-dried in oven for 6 hours at $60^{\circ} \mathrm{C}$, powdered and filtered.

Moisture analysis (AOAC 2012). Moisture content was analyzed using standard method of AOAC (2012). Briefly, mulberry leaf powder (2 g) was dehydrated in oven for 6 hours at $105^{\circ} \mathrm{C}$, desiccated for 15 minutes, and weighed.

Extraction (Jeszka-Skowron et al. 2014, modified). Mulberry leaves were macerated for 24 hours using ethanol $65 \%$ at a ratio of 1:10 (leaf powder: solvent). At the first 6 hours, the mixture was shaken in a shaker at $125 \mathrm{rpm}$, and left. Macerated substance was collected after filtration using filter paper. This maceration condition was replicated 3 times. The solvent was then removed using rotary evaporator, yielding an extract paste. The $\%$ extract yield was then determined as follows:

$\%$ yield $=\frac{\text { extract weight }}{\text { water }- \text { free simplicia weight }} \times 100 \%$

Phytochemical Analysis (Harborne 1987). In this section, determination of alkaloid, tanin, flavonoid,saponin, steroid, and triterpenoid was carried out.

Determination of incubation time using conjugated dienes (Esterbauer 1989). A mixture consisting of $2 \mathrm{ml}$ buffer phosphate $(0.1$ $\mathrm{M}, \mathrm{pH} 7), 2 \mathrm{ml}$ linoleic acid (50 mM; in ethanol $99.80 \%$ ), and $1 \mathrm{ml}$ deionized water was prepared and then placed in screw pan bottle. The mixture 
was incubated at $400^{\circ} \mathrm{C}$, and its absorbance was measured till obtaining the maximum one, with a descending value. Absorption intensity was measured by adding $50 \mu \mathrm{L}$ of linoleic acid previously incubated with $6 \mathrm{ml}$ of ethanol $75 \%$. The absorption was read at a wavelength of $234 \mathrm{~nm}$, while ethanol $75 \%$ was used as blank solution.

Determination of Antioxidant Activity using TBA assay (Kikuzaki \& Nakatami 1993). Ethanolic extract of mulberry leaf was made at different concentrations: $125,250,500$ and 1,000 ppm. The $\alpha$-tocopherol (200 ppm) was used as positive control, while distilled water was used as negative control. All of these samples were taken $1 \mathrm{ml}$, added with $2 \mathrm{ml}$ of buffer phosphate $(0.1 \mathrm{M}$, $\mathrm{pH} 7$ ) and $2 \mathrm{ml}$ of linoleic acid $50 \mathrm{mM}$ in ethanol $99.8 \%$.

Solution was transferred into a dark bottle with a screw cap, and incubated at $400^{\circ} \mathrm{C}$ for a particular period of time as determined previously. MDA level was measured by TBA method exactly 2 days after incubation. Briefly, one $\mathrm{ml}$ of each solution was added with $2 \mathrm{ml}$ of TCA $2 \%$ and $2 \mathrm{ml}$ of TBA $1 \%$ in a glacial acetic acid $50 \%$. Distilled water was used as blank solution, with a similar procedure. The mixture was heated at $100^{\circ} \mathrm{C}$ for 10 minutes, cooled, and centrifuged at $3,000 \mathrm{rpm}$ for 15 minutes. The absorbance was read at $532 \mathrm{~nm}$ wavelength using spectrophotometer.

Furthermore, standard curve was made. TMP solution was prepared at the following levels: 1,$5 ; 3 ; 6 ; 9 ; 12 ; 15$; and $18 \mu \mathrm{M}$. One $\mathrm{ml}$ of each solution was reacted with $2 \mathrm{ml}$ of TCA $20 \%$ and $2 \mathrm{ml}$ of TBA $1 \%$ in a glacial acetic acid $50 \%$. The mixture was heated at $100^{\circ} \mathrm{C}$ for 10 minutes, centrifuged at 3,000 rpm for 15 mininutes. The absorbance of each level of TMP was spectrophotometrically measured at $532 \mathrm{~nm}$. Distilled water was applied as blank solution.

Determination of $\alpha-$ glucosidase inhibitory activity (Sancheti et al. 2009). Inhibition against $\alpha$-glucosidase (Sigma-Aldrich, Singapore) was tested, using p-nitrophenyl- $\alpha$-D glucopyranoside (p-NPG) as substrate. In this experiment, substrate $p$-NPG was hydrolyzed by $\alpha$-glucosidase to form glucose and pnitrophenol that produces yellow color. Microplate reader was used to check color changes spectrophotometrically at $410 \mathrm{~nm}$. The measurement results were then used to calculate $\mathrm{IC}_{50}$, representing concentration of the extract able to inhibit $50 \%$ of enzyme activity.
Enzyme solution was made by dissolving $1 \mathrm{mg}$ of $\alpha$-glucosidase in $100 \mathrm{ml}$ of buffer phosphate $(\mathrm{pH} \mathrm{7})$ containing $200 \mathrm{mg}$ of bovine serum albumin (BSA). Prior to use, one ml of enzyme solution was diluted 25 times using buffer phosphate (pH 7) $100 \mathrm{mM}$ containing $200 \mathrm{mg}$ of BSA. The reagent mixture was presented in Table 1 , consisting of 25 of $\mu \mathrm{L}$ p-NPG $20 \mathrm{mM}$ as substrate, $50 \mu \mathrm{L}$ of buffer phosphate $(\mathrm{pH}$ 7) $100 \mathrm{mM}$, and $10 \mu \mathrm{L}$ of sample in DMSO $1 \%(\mathrm{~b} / \mathrm{v})$ (concentration: $10,100,250,500,1,000,2,500,5,000$, and $10,000 \mu \mathrm{g} / \mathrm{ml}$ ) and $25 \mu \mathrm{L}$ of enzyme. The reagent was incubated at $37^{\circ} \mathrm{C}$ for 30 minutes, and the enzymatic reaction was stopped by adding $100 \mu \mathrm{L}$ of $\mathrm{Na}_{2} \mathrm{CO}_{3} 200 \mathrm{mM}$. Spectrophotometric measurement was used to check absorbance at wavelength of $410 \mathrm{~nm}$ using microplate reader.

Negative control represented the reaction between substrate and enzyme in the absence of inhibitor, while blank solution represented reaction system in absence of both enzyme and inhibitor. All experimental units were made at triplicates. The \% inhibition was calculated as follows:

\% Inhibition $=\frac{\text { control absorbance }- \text { sample absorbance }}{\text { control absorbance }} \times 100 \%$

Acarbose was applied as positive control, acting as inhibitor of $\alpha$-glucosidase. Acarbose was dissolved in buffer solution and HCL $2 \mathrm{~N}$ (1:1), at various concentrations: $0.10 ; 0.50 ; 1.00$; 5.00; and $10.00 \mathrm{ppm}$ (each $10 \mu \mathrm{L}$ ). The solution was reacted with reagent mixture, with similar procedure as tested samples. The absorbance was read using microplate reader at $410 \mathrm{~nm}$.

Table 1. Reaction system of $\alpha$-glucosidase

\begin{tabular}{lcccc}
\multicolumn{5}{c}{ inhibition } \\
Solution & $\begin{array}{c}\text { Blank } \\
(\mu \mathrm{L})\end{array}$ & $\begin{array}{c}\text { Control } \\
(\mu \mathrm{L})\end{array}$ & $\begin{array}{c}\mathrm{S}_{\mathrm{o}} \\
(\mu \mathrm{L})\end{array}$ & $\begin{array}{c}\mathrm{S}_{1} \\
(\mu \mathrm{L})\end{array}$ \\
\hline Extract & - & - & 10 & 10 \\
DMSO & 10 & 10 & - & - \\
Buffer & 75 & 50 & 75 & 50 \\
Substrate & 25 & 25 & 25 & 25 \\
Enzyme & - & 25 & - & 25 \\
\hline \multicolumn{5}{c}{ Incubation at $37^{\circ} \mathrm{C} 30$ minutes } \\
\hline $\mathrm{Na}_{2} \mathrm{CO}_{3}$ & 100 & 100 & 100 & 100 \\
\hline Note: $\mathrm{S}_{\mathrm{o}}=$ control; $\mathrm{S}_{1}=$ tested sample
\end{tabular}


Hasim et al.

\section{Data analysis}

Data were expressed as mean \pm standard deviation, and evaluated statistically using OneWay Analysis of Variance (ANOVA) in IBM SPSS Statistics 22. The significant difference among means was compared using Duncan test at $\alpha=0.05$. $\mathrm{IC}_{50}$ was calculated using linear regression, plotting $\%$ inhibition vs $\ln$ concentration.

\section{RESULTS AND DISCUSSION}

A previous report showed that moisture content of mulberry leaf reached $7.26 \pm 0.76 \%$, with a yield of $24.52 \%$. The desirable results of experiment could be achieved due to low moisture level of the simplicia, i.e. $<10 \%$ (BPOM 2014).

In this research, ethanol $65 \%$ was used as solvent since some studies suggested that ethanolic extracts of the mulberry plant is the best for significantly reducing glucose level. Ethanol $65 \%$ exhibited a higher efficiency in extraction of active compounds in mulberry leaf, approximately twice higher than aqueous solvent (Jeszka-Skowron et al. 2009). Further findings are also reported that ethanol and methanol at concentration of $40 \%-80 \%$ can isolate more polyphenol, flavonol, glycoside, and flavonoid over other solvents such as water, absolute ethanol and methanol.

\section{Phytochemical Profile of Mulberry Leaf Ex- tract}

As presented in Table 2, the extract was confirmend to contain flavonoid, tanin and steroid, evidenced by positive result, while other compounds such as alkaloid, saponin, and alkaloid were confirmed negative.

Table 2. Results of phytochemical analysis on mulberry leaf extract

\begin{tabular}{lc}
\hline \multicolumn{1}{c}{ Compounds tested } & Results \\
\hline Alkaloid & - \\
Flavonoid & + \\
Tannin & + \\
Saponin & - \\
Steroid & - \\
Triterpenoid & + \\
Positive sign (+) indicates that the compound is present \\
in the extract; Negative sign (-) indicates absence of the \\
compound in the studied extract
\end{tabular}

Agustina et al. (2014) found that ethanolic extract of mulberry leaf was confirmed to contain quercetin and anthocyanin. In addition, the 45-days aged leaf was also known to have $\beta$-carotene at concentration of $2,04 \mu \mathrm{g} / \mathrm{g}$. Another report showed that mulberry fruit possessed antioxidant properties reaching up to $86.79 \%$ based on DPPH assay (Natic et al. 2015). In other parts of the plant, ethanolic extract of mulberry's twigs and root barks was also confirmed to exert antioxidant and anti-tyrosine activity, in which the twig extract showed a stronger activity (Chang et al. 2011).

\section{Incubation Time}

Determination of optimum incubation time was based on conjugated diene method. As depicted in Figure 1, absorbance tends to cotently increase. This is due to the generation of carbon radicals during propagation phase as well as continuous reactions (Allouche et al. 2010). The increment of absorbance from day 0 to day 4 could indicate formation of conjugated diene hydroperoxide reaching maximum level. After this period, the absorbance showed a fluctuative condition, suggesting that conjugated diene hydroperoxides began to decompose, which in turn forms malonaldehyde (MDA) as product of lipid peroxidation.

We also found that the absorbance was recorded to rise in day 6 , which could be ascribed to temperature level and less stable oxygen during period of incubation. Compared to absorbance in day 4, the value in day 6 was lower; thus, incubation time was considered to reach maximum level for 4 days. Based on this finding, analysis of potential antioxidant could be carried out about 2 days after optimum production of conjugated diene hydroperoxide. This is understandable that, in day 6 , most hydroperoxide compounds were decomposed to form MDA.

Formation of conjugated dienes is influenced by several factors, such as heat, light, $\mathrm{pH}$, oxygen, metal ions, and lipid radicals.

\section{Oxidation of Linoleic Acid}

Figure 2 showed that the highest concentration of MDA was attributed to negative control. This is clear that MDA radicals are extensively produced due to absence of antioxidant compounds. In this case, high quantity of MDA is a result of oxidation process towards linoleic acid. 


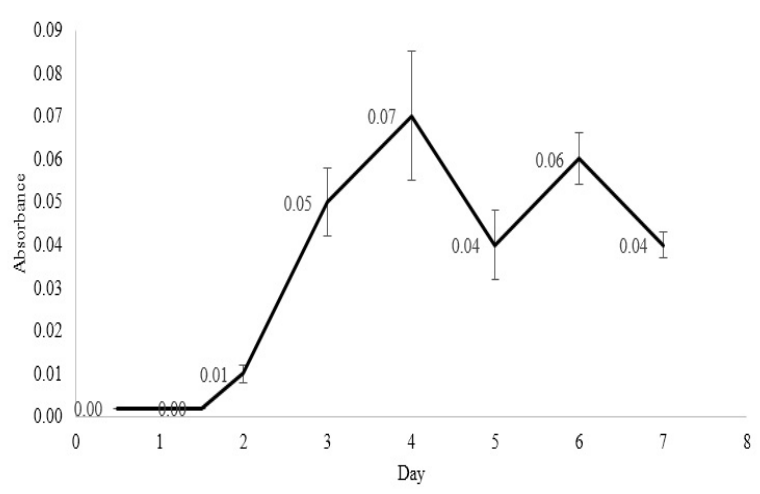

Figure 1. Changes in linoleic acid absorbance during 7 days of incubation time

The opposite result was found in group of positive control ( $\alpha$-tocopherol), in which the formation of MDA was significantly lower compared to other groups $(\alpha=0.05)$, reaching up to 3.08 with inhibitory activity of $62.06 \%$ (exhibited in Figure 3 ). This discrepancy may result from some factors, such as purity and quality of $\alpha$-tocopherol, as well as incubation time. However, the MDA concentration was remarkably altered by mulberry leaf ethanolic extracts. Administration of the extract at dose of 125, 200, 500, and 1,000 ppm caused a meaningful effect on level of MDA, resulting in inhibition of $41.21 \% ; 45.33 \% ; 44.20 \%$; and $36.00 \%$, respectively. Meanwhile, Alfarabi et al. (2010) investigated the linoleic acid inhibition generated by extract of Piper crocatum leaves at $25,50,75,100,200 \mathrm{ppm}$ dose, yielding inhibi-

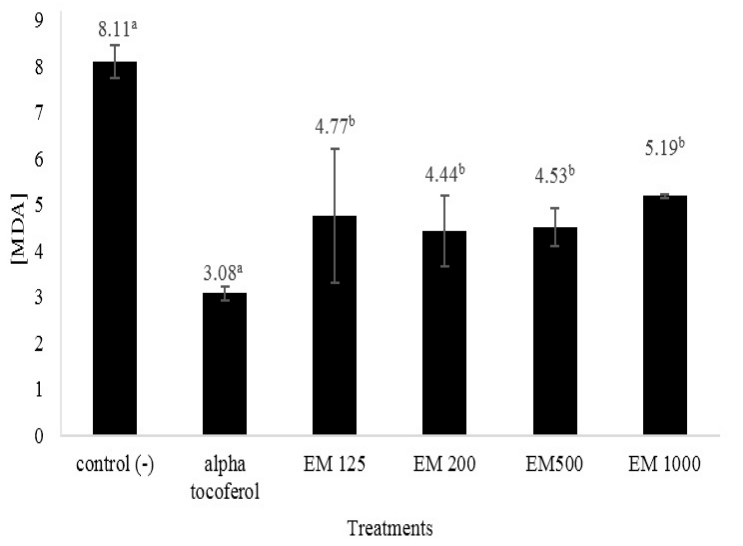

Figure 2. Effects of various treatments on MDA concentration. EM: extract ethanol mullberry.Those with different letters differ significantly at $\mathrm{p}<0.05$ tion of $44.31 \%, 56.30 \%, 63.00 \%, 72.68 \%$ and $80.4 \%$ respectively. In this present study the $\%$ of inhibition up to $200 \mathrm{ppm}$ dose of showed the highest alteration. Based on this finding, the recommended concentration of the extract was 200 $\mathrm{ppm}$. However, we need to emphasize that statistical evaluation demonstrated a non sisgnificant difference in the level of MDA as well as in \% inhibition among mulberry extract treatments. Additionally, our data confirmed that $\alpha$-tocopherol, as positive control, was noted as the strongest inhibitor over all other groups of treatments in this experiment.

Research focusing on antioxidant properties of mulberry leaf has been discussed by other researchers. Katsube et al. (2009) reported the antioxidant activity of mulberry leaf ethanolic extract against oxidation of LDL. The leaf extract was isolated by ethanol $60 \%$ as solvent, in which quercetin and rutin were found as the predominant flavonol glycosides. Jezka-Skowron et al. (2014) revealed that mulberry leaf extracted by ethanol $65 \%$ contained an appreciable amount of total phenolic, being $20 \%$ higher than sample extracted by acetone, while also producing lower TBA value. All of these reports could enrich the scientific evidence of mulberry leaf as a source of antioxidative compounds.

\section{Inhibitory activity against $\alpha$-glucosidase}

Our experiment successfully confirmed the inhibitory activity of mulberry leaf extracts

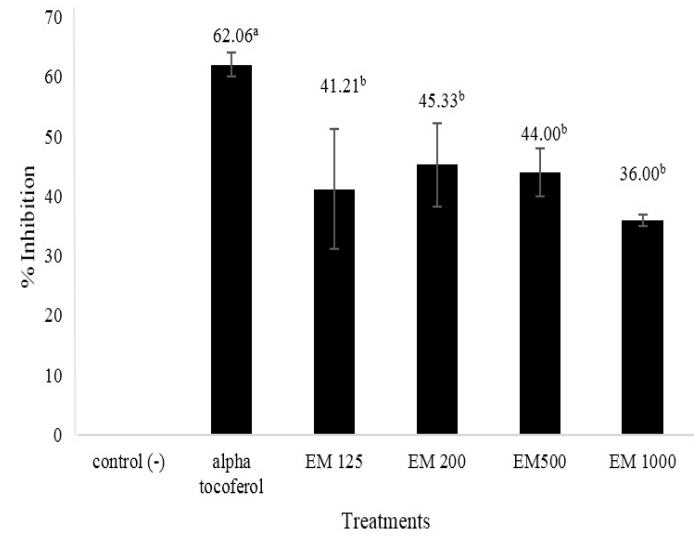

Figure 3. Effects of various treatments on \% inhibition. EM: extract ethanol mullberry. Those with different letters differ significantly at $\mathrm{p}<0.05$ 
towards $\alpha$-glucosidase, as exhibited in Figure 4. In this case, inhibitory activity of the extract was expressed as $\mathrm{IC}_{50}$, reaching up to $309.82 \pm 5.72$ $\mu \mathrm{g} / \mathrm{ml}$ (Table 3). The value of $\mathrm{IC}_{50}$ from mulberry leaf extracts was higher than that from acarbose $(0.25 \pm 0.02 \mu \mathrm{g} / \mathrm{ml})$, meaning that acarbose was much stronger as inhibitor over the studied extracts.

Inhibitory properties of mulberry leaf extracts against $\alpha$-glucosidase are linked to presence of bioactive compounds such as alkaloid which is present in form of 1-deoxynojirimycin (DNJ). As reported by Kwon et al. (2011), DNJ acts as competitive inhibitor against $\alpha$-glucosidase, thereby causing the reduction of glucose level after carbohydrate intake (postprandial hyperglycemia). Another study also found that chemical structure of DNJ is identic to D-glucose; therefore, it could alleviate absorption of D-glucose in the walls of small intestine (Voss et al. 2007).

Regarding to phytochemicals, it is noteworthy that alkaloid is not found according to qualitative experiment, which caused the low content of DNJ. Absence of alkaloid in the studied extract could be the major reason of the weak inhibition against $\alpha$-glucosidase. Besides alkaloid, flavonoid is also reported as a significant compound responsible for inhibition of $\alpha$-glucosidase (Kazeem et al. 2013). Flavonoind compound may exist in many forms, such as rutin, quercetin, and chlorogenic acid, in which they are scientifically confirmed able to inhibit $\alpha$-glucosidase (Hunyadi et al. 2012). Previously, in vitro experiments reported that flavonoid and polyphenol are bioactive compounds that enable to reduce activity of $\alpha$-glucosidase in intestine and $\alpha$-amylase pancreatic (Koh et al. 2010, Pereira et al. 2011).

Furthermore, inhibition of such enzymatic actions could be performed by other sources. Yilmazer-Musa et al. (2012) investigated the in-

Table 3. Comparison of $\mathrm{IC}_{50}$ value between ethanolic extract and acarbose

\begin{tabular}{lc}
\hline \multicolumn{1}{c}{ Inhibitors } & $\mathrm{IC}_{50}(\mu \mathrm{g} / \mathrm{ml})^{*}$ \\
\hline $\begin{array}{l}\text { Mulberry leaf extract } \\
\text { (by ethanol 65\%) }\end{array}$ & $309.82 \pm 5.72$ \\
Acarbose & $0.25 \pm 0.02$ \\
\hline
\end{tabular}

The mark * means that data are expressed as mean \pm standard deviation $(\mathrm{n}=3)$ hibition of $\alpha$-glucosidase generated by extracts of grape seed, green tea, teavigo, and white tea, yielding $\mathrm{IC}_{50}$ value of $1.20 ; 0.50 ; 0.30$; and 2.50 $\mu \mathrm{g} / \mathrm{ml}$, respectively. $\mathrm{IC}_{50}$ of rich grape pomace extract was $1,630 \mu \mathrm{g} / \mathrm{ml}$, reported by Hogan et al. (2010); meanwhile, Rubilar et al. (2011) reported $\mathrm{IC}_{50}$ of various extracts, such as murta (Ugni molinae Turcz.) leaf and fruit (215.70 and $61.30 \mu \mathrm{g} /$ $\mathrm{ml}$, respectively), and maqui (Aristotelia chilensis) leaf and stem $(2.40$ and $189.40 \mu \mathrm{g} / \mathrm{ml}$ respectively). Gomathi et al. (2012) investigated $\mathrm{IC}_{50}$ of ethanolic extract of Evolvulus alsinoides, reaching value of $86 \mu \mathrm{g} / \mathrm{ml}$. In this present work, the $\mathrm{IC}_{50}$ of mulberry leaf ethanolic extract was higher than that of other extracts reported. As conclusive remark, we need higher concentration of the extract enabling to generate a stronger inhibition against $\alpha$-glucosidase.

\section{CONCLUSION}

Mulberry (Morus alba L.) leaf extract isolated by ethanol $65 \%$ could alleviate production of MDA. Some bioactive compounds (i.e. flavonoid, tannin,steroid) present in the extract are responsible for bioactivity of the extract. Moreover, the extract was also confirmed capable of producing inhibitory action against $\alpha$-glucosidase, although the inhibition was lower compared to acarbose.

\section{ACKNOWLEDGEMENT}

The authors would like to thank Department of Biochemistry, Faculty of Mathematics and Natural Sciences and Laboratory of Department of Food Science and Technology, Faculty of Agricultural Engineering and Technology, IPB University for research facilities. The authors have no conflict of interest.

\section{REFERENCES}

[AOAC] Association of Official Analytical Chemist. 2012. Official Method of Analysis of the Association of Official Analytical of Chemist. Arlington: The Association of Offiicial Anaytical Chemists.

Alfarabi M, Bintang M, Suryani, Safithri M. 2010. The Comparative Ability of Antioxidant Activity of Piper crocatum in Inhibiting Fatty Acid Oxidation and Free Radical 
Scavenging. Hayati J Biosci. 17(4):201204. https://doi.org/10.4308/hjb.17.4.201.

Agustina L, Mustabi J, Jamilah. 2014. Zat Bioaktif dan Daya Hambat Antibakteri Daun Murbei. [Proceeding] Seminar Nasional Agribisnis (page 1-6), 9 September. Semarang: Univesitas Diponegoro.

Allouche Y, Beltrán G, Gaforio JJ, Uceda M, Mesa MD. 2010. Antioxidant and antiatherogenic activities of pentacyclic triterpenic diols and acids. Food Chem Toxicol 48(10):2885-2890. https://doi. org/10.1016/j.fct.2010.07.022.

Amrun M, Umiyah, Umayah E. 2007. Uji Aktivitas antioksidan ekstrak air dan ekstrak Metanol Beberapa Varian Buah Kenitu (Chrysophyllum cainito L.) dari daerah Jember. Berk Penel Hayati 13:45-50.

Arabshahi-Delouee S, Urooj A. 2007. Antioxidant properties various solvent extract of mulberry (Morus indica L.) leaves. Food Chem 102(4):1233-1240. https://doi. org/10.1016/j.foodchem.2006.07.013.

[BPOM] Badan Pengawas Obat dan Makanan. 2014. Peraturan Kepala Badan Pengawas Obat dan Makanan Republik Indonesia Nomor 12 Tahun 2014 Tentang Persyaratan Mutu Obat Tradisional. Jakarta: BPOM.

Barclay AW, Petocz P, McMillan-Price J, Flood VM, Prvan T, Mitchell P, Brand-Miller JC. 2008. Glycemic index, glycemic load, and chronic disease risk-ameta-analysis of observational studies. Am J Clin Nutr 87(3):627-637. https://doi.org/10.1093/ $\mathrm{ajcn} / 87.3 .627$.

Castellano JM, Guinda A, Delgado T, Rada M, Cayuela JA. 2013. Biochemical basis of the antidiabetic activity of oleanolic acid and related pentacyclic triterpenes. Diabetes 62(6):1791-1799. https://doi. org/10.2337/db12-1215.

Chang LW, Juang LJ, Wang BS, Wang MY, Tai HM, Hung WJ, Chen YJ, Huang MH. 2011. Antioxidant and antityrosinase activity of mulberry (Morus alba L.) twigs and root bark. Food Chem Toxicol 49(4):785-790. https://doi.org/10.1016/j.fct.2010.11.045.

Chung HI, Kim J, Kim JY, Kwon O.2013. Acute intake of mulberry leaf aqueous extract affects postprandial glucose response after maltose loading: Randomized double- blind placebo-controlled pilot study. J Funct Foods 5(3):1502-1506. https://doi. org/10.1016/j.jff.2013.04.015.

Efendi R, Damaynthi E, Kustiyah L, Kusumorini N.2010. Pengendalian kadar glukosa darah oleh the hijau dan atau the daun murbei pada tikus diabetes. Jurnal Gizi dan Pangan 5(2): 87-94. https://doi.org/10.25182/ jgp.2010.5.2.87-94.

Esterbauer H, Striegl G, Puhl H, Rothene er M. 1989. Continuous monitoring of in vztro oxidation of human low density lipoprotein. Free Radic Res Commun 6(1):67-75. https://doi. org/10.3109/10715768909073429.

Gomathi D, Kalaiselvi M, Ravikumar G, Sophia D, Gopalakrishnan VK, Uma C. 2012. Secondary metabolite credentials of Evolvulus alsinoides by high performance thin layer chromatography (HPTLC). J Biomed Res 26(4):295-302. doi: 10.7555/ JBR.26.20110128.

Huang HP, Ou TT, Wang CJ. 2013. Mulberry and its bioactive compounds, the chemoprevention effects and molecular mechanisms in vitro and in vivo. J Tradit Complement Med. 3(1):7-15. https://doi. org/10.4103/2225-4110.106535.

Harborne JP. 1987. Metode Fitokimia. (Padmawinta K, Soediro I, penerjemah). Bandung: ITB.

Hunyadi A, Martins A, Hsieh TJ, Seres A, Zupko I. 2012. Chlorogenic acid and rutin play a major role in the in vivo antidiabetic activity of Morus alba leaf extract on type II diabetic rats. Plos One 7(11): e50619 1-7. https://doi.org/10.1371/journal. pone. 0050619 .

Hogan S, Zhang L, Li J, Sun S, Canning C, Zhou K. 2010. Antioxidant rich grape pomace extract suppresses postprandial hyperglycemia in diabetic mice by specifically inhibiting alpha-glucosidase. Nutr Metabo 7(71):1-9. https://doi.org/10.1186/17437075-7-71.

Jeszka-Skowron M, Kobus J, Flaczyk E. 2009. Evaluation of antioxidant activity of Morus alba leaf extracts. Bromatol Chem Toksykol. 42:2791-2796.

Jezka-Skowron M, Flaczyk E, Jeszka J, Krejpcio Z, Krol E, Buchowski MS. 2014. Mulberry leaf extract intake reduces hyperglycaemia 
in Streptozotocin (STZ)-induced diabetic rats fed high-fat diet. J Funct Foods 8:9-17. https://doi.org/10.1016/j.jff.2014.02.018.

Katsube T, Tsurunaga Y, Sugiyama M, Furuno T, Yamasaki Y. 2009. Effect of air-drying temperature on antioxidant capacity and stability of polyphenolic compounds in mulberry (Morus alba L.) leaves. Food Chem 113(4):964-969. https://doi.org/10.1016/j. foodchem.2008.08.041.

Kazeem MI, Raimi OG, Balogun RM, Ogundajo AL. 2013. Comparative study on the $\alpha$-amylase and $\alpha$-glucosidase inhibitory potential of different extracts of Blighia sapida Koenig. Am J Res Commu 1(7): 178-192.

Kikuzaki H dan Nakatami N. 1993. Antioxidant effects of some ginger constituens. J Food Sci 58(6):1407-1410. https://doi. org/10.1111/j.1365-2621.1993.tb06194.x.

Koh LW, Wong LL, Loo YY, Kasapis S, Huang D. 2010. Evaluation of different teas against starch digestibility by mammalian glycosidases. J Agric Food Chem 58(1):148-154. https://doi.org/10.1021/jf903011g.

Kwon HJ, Chung JY, Kim JY, Kwon O. 2011. Comparison of 1-deoxynojirimycin and aqueos mulberry leaf extract with emphasis on postprandial hypoglycemic effects: in vivo and in vitro studies. J Agric Food Chem 59(7): 3014-3019. https://doi. org/10.1021/jf103463f.

Natic MM, Dabic DC, Papetti A, Aksic MMF, Ognjanov V, Ljubojevic M, Tesic ZL. 2015. Analysis and characterisation of phytochemicals in mulberry (Morus alba L.) fruits grown in Vojvodina, North Ser- bia. Food Chem 171:128-136. https://doi. org/10.1016/j.foodchem.2014.08.101.

Pereira DF, Cazarolli LH, Lavado C, Mengatto V, Figueiredo MSRB, Guedes A, Pizzolatti MG, Silva FRMB. 2011. Effects of flavonoids on $\alpha$-glucosidase activity: Potential targets for glucose homeostasis. Nutrition 27(11-12):1161-1167. https://doi. org/10.1016/j.nut.2011.01.008.

Rubilar M, Jara C, Poo Y, Acevedo F, Guitierrez C, Sineiro J, Shene C. 2011. Extracts of maqui (Aristotelia chilensis) and murta (Ugni molinae Turcz.): Source of antioxidant compounds and $\alpha$-glucosidase $/ \alpha-$ amylase inhibitors. Am J Pharmacol Toxicol 59(5):1630-1637. http://pubs.acs.org/ doi/abs/10.1021/jf103461k.

Sancheti S, Sancheti S, Yum SS. 2009. Chaenomeles sinensis: A potent $\alpha$-and $\beta$-glucosidase inhibitor. American J Pharm Toxicol 4(1): 8-11.

Voss AA, Diexz-Sampedro A, Hirayama BA, Loo DDF, Wright EM. 2007. Imino sugars are potent agonists of the human glucose sensor SGLT . Mol Pharmacol 71(2):628-634. https://doi.org/10.1124/mol.106.030288.

Yilmazer-Musa M, Griffith AM, Michels AJ, Schneider E, Frei B. 2012. Grape seed and tea extracts and catechin 3-gallates are potent inhibitors of $\alpha$-amylase and $\alpha$-glucosidase activity. J Agric Food Chem 60(36):8924-8929. https://doi. org/10.1021/jf301147n.

[WHO] World Health Organization. 2015. Media Centre. Diabetes. Fact sheet No 312. World Health Organization. https://www. who.int/nmh/publications/fact_sheet_diabetes_en.pdf. [Accessed 20 June 2015]. 